\title{
Théodore de Bèze, Abraham sacrifiant. Tragedie Françoise
}

\section{Michele Mastroianni}

\section{(2) OpenEdition}

1 Journals

\section{Edizione digitale}

URL: http://journals.openedition.org/studifrancesi/9829

DOI: $10.4000 /$ studifrancesi.9829

ISSN: 2421-5856

\section{Editore}

Rosenberg \& Sellier

\section{Edizione cartacea}

Data di pubblicazione: 1 octobre 2007

Paginazione: 427-428

ISSN: 0039-2944

\section{Notizia bibliografica digitale}

Michele Mastroianni, «Théodore de Bèze, Abraham sacrifiant. Tragedie Françoise», Studi Francesi

[Online], 152 (LI | II) | 2007, online dal 30 novembre 2015, consultato il 07 janvier 2021. URL: http:// journals.openedition.org/studifrancesi/9829; DOI: https://doi.org/10.4000/studifrancesi.9829

Questo documento è stato generato automaticamente il 7 janvier 2021.

\section{(c) (i) (9)}

Studi Francesi è distribuita con Licenza Creative Commons Attribuzione - Non commerciale - Non opere derivate 4.0 Internazionale. 


\title{
Théodore de Bèze, Abraham sacrifiant. Tragedie Françoise
}

\author{
Michele Mastroianni
}

\section{NOTIZIA}

THÉODORE DE BÈzE, Abraham sacrifiant. Tragedie Françoise, édition critique établie par Marguerite SOULIÉ et Jean-Dominique BEAUDIN, Paris, Champion («Textes de la Renaissance», 122), 2006, pp. 121.

1 Dopo l'edizione a cura di K. Cameron, K.M. Hall e F. Higman (Genève, Droz, 1967) - il cui testo è stato riprodotto da $\mathrm{P}$. De Capitani nel corpus del «Théâtre français de la Renaissance» diretto da E. Balmas e M. Dassonville (1986) - compare ora una nuova edizione critica che, dal punto di vista testuale, segue i criteri della precedente (testo base, quello dell'editio princeps del 1550), arricchendo l'apparato delle varianti con la registrazione di variazioni grafiche che possono eventualmente corrispondere a pronunce differenti, a un'oscillazione nell'accordo grammaticale, a una distinzione tra i tempi verbali. L'edizione Soulié-Beaudin completa inoltre l'esame delle cinquecentine collazionando anche l'edizione del 1551, in precedenza trascurata. Accurata e puntuale, l'introduzione ricostruisce i rapporti di genere di questa pièce, la prima a porre il problema della tragédie sainte in una prospettiva che non è più quella dei mystères medievali ma che è quella della difesa o dell'opposizione a un teatro rinascimentale che si vuole ispirato ai modelli classici greci e latini. 